\title{
Global Service Network and the Choices of China
}

\author{
Jun Zhang \\ School of Economics, Jinan University \\ 601 West of Huangpu Road, Guangzhou 510632, China \\ Tel: 86-20-8522-1478 E-mail: tjunzh@jnu.edu.cn
}

\begin{abstract}
Global production network has become the main competitive force on the micro level in the process of globalization, which is monopolized by transnational corporations. After the transfer of manufactures from developed countries to developing countries, global transfer turns to service industry, especially the transfer of knowledge intensive services such as financial services, professional services, information services, research and development and technology. The paper constructs a framework to analyze the network and its impact on globalization and how China's knowledge intensive service industry has developed by being involved in the global service network. It draws the conclusion that by involving in global service network, which incorporates knowledge transfer mechanism, the developing countries can acquire later-comer advantage and develop their industry in some period, but the lock-in trap would be damage to their further development.
\end{abstract}

Keywords: Knowledge Intensive Service Industry, Global Service Network, Transnational Corporations, China

\section{Introduction}

In many parts of the world the production of output is changing from a machine or manufacturing economy to an information economy and from an industrial to a service economy. Global production network(GPN), which is monopolized by transnational corporations(TNCs), has become the main force competing with each other in the process of globalization.

Gereffi proposed the concept of global value chain (GVC) and classified GVC as producer-driven and consumer-driver. He also systematically organized the study of the pattern and the mechanism of industrial upgrading.(Gereffi,1999) Ernst constructed a model of the global production network, which he defined as series of enterprises which produced and provided production and service. He applied the model to analyze the global transfer of manufacture such as the information industry.(Ernst,1999) Based on his research, Ernst found that flagship not only outsourced manufacture but also high-end knowledge intensive sectors. At the same time, the effect of the global production network on knowledge diffusion was neglected, especially its effect on knowledge intensive supporting services and knowledge diffusion to low cost areas. Ernst also thought it was necessary to focus research on the widely dispersed knowledge intensive service industry, which was closely related to production. (Ernst,2000) Even though the service industry has no formal R\&D, it can bring learning and innovation, and so the service industry should be incorporated in this framework.

There is extensive research on knowledge intensive service industries worldwide. Wiles, Windrum, Tomlinson,among others, defined knowledge intensive service industry and classified them.(Miles,1997; Windrum, Tomlinson, 1999) Weijiang and Muller explored the basic theories about service innovation and the innovation of knowledge intensive service industry. They undertook research on the innovation patterns and paths of the knowledge intensive service industry and discussed the role of the knowledge intensive service industry on the national and regional innovation system.(Weijing,2004; Muller,2001) Strambach discussed the knowledge intensive service industry as the carrier of knowledge transfers. (Strambach,2001) Penato and Arianna analyzed the development of the knowledge intensive service industry from the aspects as inner relationship (including formal and informal organization structure), exterior relationship (including exterior environment, customers and competitors) as well as the relationship between inner network and exterior network. (Penato, Arianna, 2003) The above researches focus on the definition, the classification and the characteristics of knowledge intensive service industry as well as its role in knowledge transfer and innovation system, but no one talks about the development of the industry with the progress of globalization and global industry transfer.

\section{The formation and the basic structure of global service network}

With services sectors, especially knowledge-intensive service sectors being higher value added sectors, more and more service-oriented multinational companies break down the service industrial chains and transfer parts of them to developing countries to make full use of the cheap labor resources along with high technology. This forms a global service network (GSN) with the service-oriented multinational corporations from developed 
countries as the core. With their control of high technology and market resources they establish market control. There are also high and low level suppliers. (refer to Figure 1).

The global service network is led by multinational companies from developed countries such as the United States, Europe, Japan and other developed countries. Their competitive advantage comes from the experiences and methods developed in highly advanced service market in the home countries, day-to-day accumulated resources, long established reputation and image of the companies gained in fierce international competition and abundance of high-level human capital. For better allocation of resources in world competition, the flagships transfer parts of their knowledge-intensive service industries to developing countries. The United States controls about two-thirds of the world markets, Japan and Europe about one-third and the receiving countries are mostly from Asia. Currently there are many countries that receive transfers of knowledge-intensive service industries from multinationals in United States, Europe and Japan. They include Russia and Ireland in Europe, Mexico in North America, Argentina in South America, China, Korea, India, the Philippines, Malaysia and Singapore in Asia, The Czech Republic, Romania, Hungary and Estonia in Eastern Europe as well as Israel and several Caribbean countries.(refer to Table 1)

The service providers in the global service network can be classified into two types. The first type is countries who receive the transferred knowledge-intensive service industries via the transfer of the manufacturing sectors. After the establishment of the manufacturing sectors, the demand for services that support manufacturing especially producer services increased. The function of high and low level suppliers in the global production networks extend from manufacturing to design and includes product development and design and even R\&D, which in turn necessitated the transfer of knowledge intensive service industries. The major countries that received such transfers were China and Philippines. The second type are production facilities in countries who directly undertake the transfer of knowledge intensive service industries from developed countries and thus integrated into the global service network, such as India and Ireland.

The characteristics of receiving countries are, first, an intelligent, well-educated and creative human resources base. Second, the countries have low labor costs. The salary of technical and management staff in newly industrialized countries is about one tenth to one seventh of those in the same position in Britain and the United States.(Note 1) IBM, for example, pays a programmer 56 U.S. dollars per hour, while in China it pays just 12.5 U.S. dollars per hour.(Note 2) The third, in the way of industrialization these countries improve their infrastructure, business climates and technical conditions. All of these provide material conditions for their capability to provide services.

\section{The development of knowledge intensive service industry in China by engaging in global service network}

3.1 The global transfer of knowledge of intensive service industry

An indication of the rapid spread of the transfer service industry is the dominant role played by the industry in foreign investment. With the global expansion and growth of investment in knowledge-intensive service industries such as finance, insurance, information, accounting and legal services to facilitate global trade, the structure of world trade in services changed a lot. The cross-border investment of the service industry and the rapid growth of the knowledge-intensive service trade accelerated the international transfer of knowledge-intensive service industries. Outsourcing in the market for global software and information services is increasing in the rate of $20 \%$ yearly, increasing from 510 billion U.S. dollars in 2003 to 2 trillion U.S. dollars in 2010. It covers finance, insurance, health care, human resources, asset management, customer relationship, marketing and so on.

\subsection{China engaging in global service network}

The transfer of manufacturing processes by transnational companies increased the demand for service industry transfer. Service companies had to move globally to provide services and support networks. The global transfer of services provided an opportunity for developing countries such as China to engage in the global service network. As a result China's service network developed rapidly.

In the software industry, for example the flagships in the global software network are multinational companies from the top three countries of the U.S., EU and Japan, such as Microsoft, IBM, HP and so on. The United States has for a long time been the leader with core technologies and ability to set standards. Transnational corporations from the United States monopolized more than $90 \%$ of the infrastructure software in the world. With the international division of labor in software industry, the software multinational companies from the United States, EU and Japan transfer domestic production to low-cost developed countries and developing countries, providing 
an opportunity for these countries to participate in the global software market. With the expansion of the service markets, the production chains transferred by the flagships increased and as a result the local service providers expanded their capabilities in areas such as application and infrastructure management, consulting, systems integration and software services. Flagships began to specialize their operation in different countries. For example, instead of establishing research institutions in all countries as before, they develop software in R\&D centers in selected countries. On the other hand, the flagships kept the core and high-end technology in home country in order to maintain innovative capability and competitiveness.

The software vendors from India, Ireland and so on grew up rapidly by undertaking businesses transferred by flagships. They are the second layer in global software network and countries having strength in software industry. In addition to India and Ireland, China, Russia, Brazil, Vietnam, the Philippines and other emerging countries have the option of transferring software services because of their high level of education and low wages, and they constitute the third layer in global software network. The software vendors in this layer are mostly engaged in the low value-added production chains of software industry but with great potential for development.

As a country in the third layer in the global software network, China was slow in undertaking the transferred software businesses, but is now growing rapidly. In the first quarter of 2008, the scale of domestic software outsourcing market reached 3.927 billion RMB Yuan with a year-on-year rise of $25.27 \%$. At present, the software industry in China is still behind that of countries in the second layer such as India and Ireland. The overall size of China's software market is also small and in the early stage of development, but with its unique advantages many transnational corporations are considering it as a strategic center.

There are mainly three ways for China to participate in the global software network. The first, China undertakes businesses through the subsidiaries set up by foreign multinational companies or the offshore development center (ODC) in China, the value of which is largest. Multinational companies such as IBM, Microsoft, HP all transfer their own software business or that from the global headquarters. In addition the R\&D centers in China by foreign multinational companies are also the important sources for China to undertake the transferred software industry. Currently the software businesses transferred from the U.S. market are through the R\&D centers of American multinational corporations in China. The second is to undertake business directly from contractors or foreign subcontractors. The volume of this business is large, but the value is low. The third is to undertake businesses through service agencies.

\subsection{The benefits from engaging in global service network}

Engaging in global service network has greatly aided the development of the service industry in China. The benefits are the following.

First, engaging in the global service network is an important way for China's service companies to acquire advanced foreign technology, management experience and access to international markets.

Set using software industry as an example. Flagships in the software global production network have formed matured system of enterprise technology standards. Meeting its technical standards is the prerequisite to undertake the transferred businesses and become a software provider in software global production network. Through participation in software global production network, domestic software companies can learn foreign advanced technology and gain management experience, as well as upgrade the professional necessary skills to complete businesses in industrial chain. For example, HP China provides solutions and industry experience for partners in the procurement from and transferring businesses to China, which helps to improve the capabilities of China's software companies. After being the software outsourcing company of E5Systems, Kingdee established a "software factory" with 3000 employees in Shenzhen with the assistance of E5Systems, which is responsible for the software outsourcing business in North American market. The subsidiaries set up in China by software flagships from the European countries and the United States to cope with the transfer of businesses provide matured business model for Chinese software enterprises. The operation centers set up by Indian suppliers in China brought improved procedures and technologies with spillover effects. In addition, the R\&D centers set up by multinational companies in cope with the transfer of businesses further enhanced the strength of the software industry in China.

To meet the standards of flagships and improve the quality of businesses, software companies in China achieve all kinds of certifications, which enhance their level of project management and process management capabilities. Since Neusoft Co., Ltd. passed assessment of the CMMI Level5 in 2004, China has become the fourth country with CMMI Level5 certification after the United States, India and Japan. By the end of 200638 software enterprises have achieved CMM5 (including CMMI5) certification in China. 23 enterprises achieved CMM4 
(including CMMI4) assessment, and more than 200 software enterprises achieved CMM3 (including CMMI3) or above assessment. In addition 2136 enterprises achieved systems integration qualification.

Secondly, there is a big improvement of China's service industry in general.

The software industry in Beijing, Shanghai, Guangzhou, Shenzhen, Dalian, Hangzhou, Xi'an and other places developed rapidly. Dalian and Xi'an serve mainly the Japanese market. Beijing and Shanghai began to open the European and American markets. Shenzhen and Guangzhou serve mainly Southeast Asia, Hong Kong and Macau. The model set up by the software industry in Shenzhen and Hong Kong gets orders in Hong Kong and does development in Shenzhen. There were more than 700 software companies in Hong Kong, of which more than 200 set up branches in Shenzhen, thus forming the model of "shop in front and factory at back" for the software industry. The average growth rate reached $40 \%$ during the 10th Five Year Plan Period. A clustering effect is evident as there are 11 national software industry bases concentrated in Beijing, Shanghai and other cities, six national software export bases, 29 the State Torch Program software industry bases and 172 state-level key software companies, and 41 export-oriented enterprises. In 2007 the contracted software exports was almost 1.9 billion U.S. dollars (not including embedded software), an increase of $64.89 \%$ comparing to the same period in 2006. There were 1179 registered software export enterprises. The software export markets are diversified. In 2007 the number of export markets (regions) reached 94, 35 more than that in 2006.

Thirdly, the service companies in China enhance their abilities by engaging in global service network, moving up to high value-added industry chains. Some companies even construct their global service networks.

With the software businesses transferred from Japanese market as an example, the Japanese companies initially only transferred the coding businesses to China's software enterprises in order to reduce costs. This enabled China's software enterprises to participate in software development by learning software knowledge and management experience from Japanese companies. By a deeper understanding of the needs of their Japanese customers, Chinese enterprises are able to complete large-scale developments. Finally, by further enhancing their technical capabilities and management, Chinese enterprises are now able to completely undertake the transferred businesses from Japanese customers. The software development projects performed by Chinese companies are mainly for the European and American market, which indicates the software industry is, with its accumulation of experience and enhancement of capability, moving up to the high and middle end of the industry chain. The business undertaken by China's software industry is in financial services, telecommunications, and software localization and so on, and is gradually moving up to the high value-added industrial chains of the software industry.

In addition, the service vendors in China are gradually becoming aware of the importance of brand, and the industrial clustering effect is also increasingly obvious. With the strengthening of international competitiveness of the whole industry, the service industry in China develops rapidly.

\section{Conclusion}

The global service industry, which acts as the knowledge organization and transfer point has tremendous spillover potential for the developing countries. And, based on the above analyses, the knowledge intensive service industry in developing countries such as China are achieving rapid development and acquiring late-comer advantage by engaging the global service network. To realize that the competition in world economy shifts to the framework of global network monopolized by the transnational corporations is important for developing countries. When they are involved in such a network, they can better implement the strategy of being close to flagships and moving up to the high value-added chains. At present, the global knowledge intensive services market is controlled by the translational companies from the United States, Europe and Japan. By being closer to flagships, more advanced technical expertise, marketing concept and scientific management experience can be learned. By participating in the strategic alliance of flagships, China can undertake more knowledge intensive service industries like financial services, information services, computer applications, and move up to the upstream of the value chain with high added value components as software development, research and development, product design, financial accounting and financial background services.

There are also risks if the developing countries rely too much on the relationship between transnational corporations as the flagship and suppliers. The lock-in effect may be barrier for developing countries when they are on their way of industry upgrading. China is in the dilemma. China has developed its manufacturing a lot by engaging in global production network, but now it is hard for it to make further progress in industry upgrading. It is also one of the questions left for further research.

The last of the big tasks for China is to improve its own competitiveness. In order to attract the international 
transfer of knowledge intensive service industries and make full use of spillover effects, China's knowledge intensive service firms need to strengthen their competitive ability. The effective way to international recognition is to achieve industrial assessment such as CMMI, CMM, PCMM, ISO27001/BS7799, ISO20000 and SAS70. It is also very important to have abundant talents. When it is time for China to be the flagship and build its own networks, having enough talents will be fatal in the global competition.

Global service network has provided a new path for the global competition and cooperation. How developing countries can make full use of this mechanism on their way to upgrading industries and sustain their development, especially for countries as China, whose manufacturing sector has been engaged in such a structure for a long time and faced the dilemma is a question for further research. Also more research is needed on the reciprocal effect between manufacture sector and service sector, and its role in structural adjustment of industries in a country.

\section{References}

Gereffi G. (1999). International Trade and Industrial Upgrading on Apparel Commodity Chain, Journal of International Economics, 48(1):37-70.

Ernst D. (1999). How Globalization Reshape the Geography of Innovation Systems, DRUID Working Paper .

Ernst D. (2000). Global Production Network and Industrial Upgrading- A Knowledge-Centered Approach, East-West Center Working Paper No.5.

Miles I. (1997). Services and the Knowledge-Based Economy: Not So Peculiar After All?, Seventh International Forum For Technology Management, Japan.

Windrum P., Tomlinson M. (1999). Knowledge-Intensive Service and International Competitiveness: A Four Country Comparison, Technology Analysis\&Strategic Management, Vol.11. (3): 391-408.

Wei Jiang, Mark Boden. (2004).Knowledge Intensive Service Industry and Innovation, Beijing Science Publishing House, (in Chinese)

Muller M., Zenker A. (2001). Business Services as Actors of Knowledge Transformation: The Role of KIBS in Regional and National Innovation Systems, Research Policy, (30): 1501-1516.

Strambach S. (2001). Innovation Processes and the Role of Knowledge-Intensive Business Services, In Koschatzky, K., Kulicke, M., Zenker A.(Eds.), Innovation Networks-Concepts and Challenges in the European Perspective, Physical Heidelberg.

Penato Fiocca, Arianna Gianola. (2003). Network Analysis of Knowledge-Intensive Services, IMP Conference, Sep.

Zhu Xiaoming. (2006).Transfer and Undertaking: Grasping the New Opportunity of Service Outsourcing,http://fdi.gov.cn/pub/FDI/wzyj/yjbg/zgwstzbg/2006chinnainvestmentreport/t20061219_68012.htm (in Chinese)

\section{Notes}

Note 1. The date is from The Trend of Transfer of Global Services and Its Effect, Study Times, No.258. (in Chinese)

Note 2. The data is from Yao Guohui. 2004 The Transfer of Global Services-the Knowledge Intensive Service Industries Transferred by Developed Countries in Scale to Developing Countries ,International Commercial Newspaper. (in Chinese)

Note 3. The data is from Lu Lu.2004.China Entered Global Outsourcing Marker, International Business Daily, September 18. (in Chinese)

Note 4. The data is from The Rising and Hardship of China's Software Outsourcing, ChinaByte, September 9,2004. (in Chinese)

Note 5. The data is from Lai Youwei.2004.The Development of International Transfer of Service Industry and The Hotspot In Attracting Investment in China, International Trade, Vol. 4. (in Chinese)

Note 6. CMM, Software Capability Maturity Model, is the description of capability in the process of organizing software development. The core of it is to look software development as a process, then supervise and research on the software development and maintenance according to the principle, thus make it more scientific and standard, which enable enterprises to better fulfill commercial targets. There are five levels in CMM. The highest level is CMM5. CMMI, Software Capability Maturity Model Integration, focuses on the four aspects as cost and 
profit, clarifying the key point, process concentration and aglity.

Note 7. The data is from Zhang Jie.2004.Neusoft Achieved CMMI Level5 Assessment, China Computer User, Vol.47. (in Chinese)

Note 8. The data is from The Industrial Environment of China Service Outsourcing, China Service Outsourcing Net, January, 2008. (in Chinese)

Note 9. The data is from The Industrial Environment of China Service Outsourcing, China Service Outsourcing Net, January, 2008. (in Chinese)

Note 10. The data is from Shanghai Software Export Enterprises are No. 1 in China, Economic Daily, March 1,2007. (in Chinese)

Note 11. The data is from Cheng Dong.2006.Software and Information Service Export Contributes A lot in Building Innovative Country,http://zys.mofcom.gov.cn/aarticle/cm/200607/20060702692092.html. (in Chinese)

Note 12. The data is from The Commercial Department: The New Trend of Software Export in China,Xinhua Net, June 23,2008. (in Chinese)

Table 1. The types of knowledge intensive service industries in different countries

\begin{tabular}{|c|c|c|c|}
\hline Countries & KIS & Countries & KIS \\
\hline Russia & Software & China & Software outsourcing, data processing \\
\hline India & $\begin{array}{l}\text { Call center, software development, engineering } \\
\text { and design, background design and data input }\end{array}$ & Philippine & $\begin{array}{c}\text { Call center, cartoons, data input, medical } \\
\text { image processing }\end{array}$ \\
\hline Israel & R\&D center, software & Singapore & $\begin{array}{c}\text { Asian information port, background } \\
\text { support of financial services }\end{array}$ \\
\hline Malaysia & $\begin{array}{c}\text { Background process, customer service, } \\
\text { information of ASEAN }\end{array}$ & The Caribbean & Data input, call center \\
\hline
\end{tabular}

Source: compiled by the author.

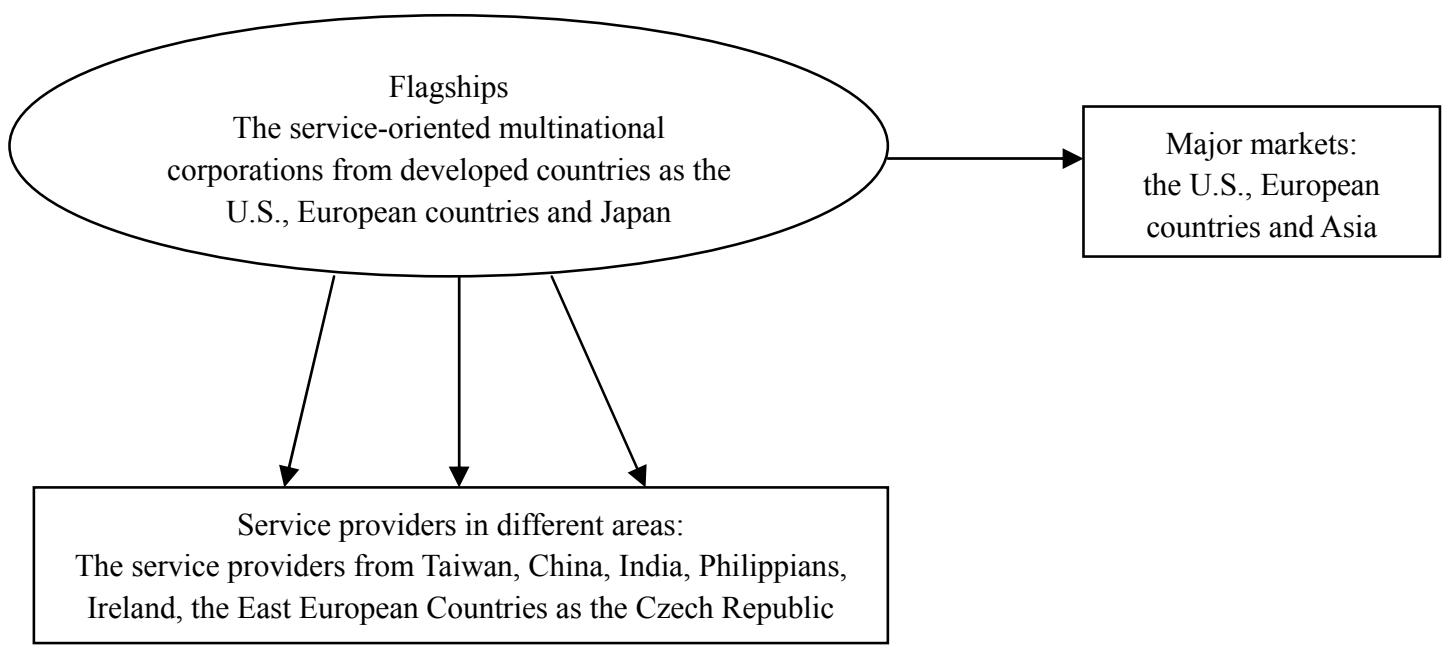

Figure 1. the Global Service Network Led by Multinational Corporations from Developed Countries 